\title{
Analisis Strategi Pemasaran Simpanan dan Pembiayaan di KJKS Manfaat Surabaya
}

\author{
Zainul Muhaimin Achmad \\ VIN Sunan AmpelSurabaya | muhaimin_za@gmail.com
}

\begin{abstract}
Become a new paradigm for achieving marketing success that is by establishing and maintaining relationships with consumers on an ongoing basis, which is called the marketing strategy. Likewise with KJKS Benefits of Surabaya. Finally the conclusion of this paper is, that: first the role of marketing KJKS Benefits of Surabaya in an effort to introduce savings and financing products to consumers is very important and also become one of the success of a company to earn profits, for the development of its products, for the continuity of its business, and for business continuity, KJKS Benefits of conducting marketing activities in the form of Advertising, Marketing, Publicity, Individual Sales, and Direct Sales.
\end{abstract}

\begin{abstract}
Abstrak: Menjadi paradigma baru untuk mencapai keberhasilan pemasaran yaitu dengan menjalin dan mempertahankan hubungan dengan konsumen secara berkesinambungan, yang disebut dengan strategi pemasaran. Begitu juga dengan KJKS Manfaat Surabaya. Akhirnya kesimpulan dari tulisan ini adalah, bahwa: pertama peranan pemasaran KJKS Manfaat Surabaya dalam usaha memperkenalkan produk simpanan dan pembiayaan kepada konsumen sangatlah penting dan juga menjadi salah satu keberhasilan suatu perusahaan untuk memperoleh laba, untuk pengembangan produk-produknya, untuk kelangsungan usahanya, serta untuk kelangsungan usahanya, KJKS Manfaat melakukan kegiatan pemasaran berupa Periklanan, Pemasaran, Publisitas, Penjualan Perseorangan, dan Penjualan Langsung.
\end{abstract}

Kata kunci: strategi pemasaran, simpanan dan pembiayaan, dan KJKS Manfaat Surabaya

\section{A. Pendahuluan}

Salah satu konsentrasi dalam ilmu ekonomi adalah pembahasan mengenai pemasaran atau marketing. Pemasaran merupakan suatu cara untuk memperkenalkan produk yang 
telah dihasilkan oleh perusahaan. ${ }^{1}$ Di dalam manajemen pemasaran, terdapat dua konsep yang sangat mendasar, yaitu kebutuhan-kebutuhan (wants). Tugas utama manajemen pemasaran adalah mendeteksi kebutuhan-kebutuhan dan keinginan-keinginan konsumen dan berusaha memenuhinya secara kontinyu.

Di era globalisasi seperti sekarang ini, banyak media yang dapat digunakan untuk memasarkan suatu produk seperti mengiklankannya di televisi atau media cetak. Manajemen perusahaan bertugas untuk memilih strategi pemasaran seperti apa yang tepat agar memenuhi target pasar yang efektif. Selain itu, perlu diperhitungkan dana yang tersedia dengan manfaat yang diperoleh dari strategi pemasaran yang dipilih perusahaan.

Menurut Chaston dalam Rizal, untuk menghadapi hal tersebut, dunia pemasaran telah mengalami pergeseran dari pemasaran transaksional menuju pemasaran relasional. Perusahaan yang menerapkan strategi pemasaran mengarahkan secara langsung upaya pemasarannya ke arah penciptaan dan penjagaan image sebagai perusahaan yang mempunyai kemampuan untuk bekerja lebih dekat dengan konsumennnya untuk memberikan pemecahan masalah pelanggan tersebut. ${ }^{2}$

Menjalin hubungan dengan pelanggan dalam jangka panjang tidak sekedar menciptakan transaksi. Menjadi paradigma baru untuk mencapai keberhasilan pemasaran yaitu dengan menjalin dan mempertahankan hubungan dengan

${ }^{1}$ Di dalam KUHD, cirikhas dari perusahaan adalah : (1) ada perbuatan dengan kualitas tertentu yang dilakukan, (2) dilakukan secara terangterangan (tidak melanggar hukum), (3) dilakukan secara terus-menerus (continue, berkesinambungan) dan (4) mencari keuntungan. Lihat: Nafi' Mubarok, Hukum Dagang: Buku Perkuliahan (Surabaya: IAIN Press, 2015), 5.

2 M. Rizal, "Implementasi Strategi CRM untuk Meningkatkan Kepuasan dan Loyalitas Pelanggan," SKEMA 1, no. 3 (November 2013): 18. 
konsumen secara berkesinambungan. ${ }^{3}$ Strategi yang dibuat pada akhirnya adalah bagaimana memenangkan hati konsumen agar dapat sukses dalam persaingan adalah berusaha mencapai tujuan dengan menciptakan dan mempertahankan konsumen.

Strategi pemasaran tidak hanya dibutuhkan pada perusahaan yang menghasilkan sebuah produk saja. Akan tetapi, perusahaan jasa seperti salah satunya Lembaga Keuangan. Baik itu Lembaga Keuangan Bank (LKB) maupun non-Bank (LKBB). ${ }^{4}$ Baik dijalankan dengan prinsip syariah atau konvensional. Khusus untuk LK dengan prinsip syariah, dengan memperhatikan jumlah penduduk muslim sebesar itu akan berpengaruh dalam berbagai aspek kehidupan di negeri ini, semisal industri perbankan dan keuangan syariah, di mana dalam satu dasawarsa belakangan mengalami kemajuan sangat pesat. $^{5}$ Dengan dikembangkannya LK yang dioperasikan berdasarkan prinsip syariah, diharapkan mobilisasi dana dan potensi ekonomi masyarakat muslim dapat dioptimalkan, yang pada gilirannya akan semakin meningkatkan peran sektor perbankan secara keseluruhan. ${ }^{6}$

Salah satu LKBB syariah adalah Koperasi Syariah,7 yang secara yuridis disebut dengan Koperasi Jasa Keuangan Syariah

3 W Arafat, Behind a Powerfull Image: Menggenggam Strategi dan Kunci-kunci Sukses Menancapkan Image Perusahaan yang Kokoh (Yogyakarta: Andi, 2006), 182.

${ }^{4}$ Lembaga keuangan ialah semua badan yang melakukan kegiatankegiatan di bidang keuangan, yang selanjutnya dibedakan antara LKBB (Lembaga Keuangan Bukan Bank) dan LKB (Lembaga Keuangan Bank) Lihat: Mubarok, Hukum Dagang: Buku Perkuliahan, 200-201.

5 Nafi' Mubarok, "Lembaga Keuangan Syariah sebagai Mustah\}iqq Zaka>h," Jurnal Al-Qa>nu>n 13, no. 2 (Desember 2010): 364.

${ }^{6}$ Nafi' Mubarok, "Tinjauan Hukum Islam Terhadap Prinsip Bagi Hasil dalam Perbankan," Maliyah 1, no. 2 (Desember 2011): 179.

7 Pada dasarnya pembatasan koperasi syariah adalah koperasi yang sudah ada disesuaikan dengan fikih (hukum Islam), untuk membedakan mana-mana perbuatan koperasi yang tidak sesuai dengan syariah dan mana-mana yang sesuai dengan syariah. Lihat: Nafi' Mubarok, Buku Ajar Mahasiswa: Hukum Asuransi dan Koperasi di Indonesia (Surabaya: Fakultas Syariah IAIN Sunan Ampel, 2013), 133. 
(KJKS), yang belakangan ini telah banyak bermunculan. Keberadaan KJKS dinilai sangat bermanfaat. KJKS dapat meningkatkan program pemberdayaan ekonomi, khususnya di kalangan usaha mikro, kecil menengah, dan koperasi melalui sistem syariah. KJKS juga mendorong kehidupan ekonomi syariah dalam kegiatan Usaha Mikro Kecil Menengah (UMKM) khususnya, dan ekonomi Indonesia umumnya.

Dalam pengembangan bidang ekonomi syariah, KJKS Manfaat Surabaya sejak awal memfokuskan lembaganya untuk bersosialisasi dan berwacana dengan luas dengan mempraktikkan ekonomi syariah. Sejak awal berdirinya pada tahun 2006 KJKS Manfaat Surabaya menunjukkan kinerja yang cukup mengagumkan. KJKS Manfaat Surabaya yang berbasis syariah dan dikelola oleh anggotanya ini, berkembang cukup pesat. Perkembangan pesat yang dialami oleh KJKS Manfaat Surabaya, merupakan dampak positif bagi peningkatan peran anggota dalam pemberdayaan ekonomi umat. ${ }^{8}$

Walaupun KJKS Manfaat Surabaya ini telah mengalami pertumbuhan setiap tahunnya, perlu disadari bahwa persaingan bisnis pada lembaga keuangan syariah ini juga sangat ketat. Sehingga KJKS Manfaat Surabaya ini dituntut untuk bertahan mengembangkan strateginya serta memilih strategi atau pendekatan pemasaran yang efektif yang mampu menciptakan, mempertahankan, dan meningkatkan kepuasan anggotanya yang pada akhirnya akan tercipta kepuasan konsumen terhadap KJKS Manfaat Surabaya.

\section{B. Strategi Pemasaran}

1. Pengertian Strategi Pemasaran

Pemasaran menurut American Marketing Association adalah proses perencanaan dan pelaksanaan rencana penetapan harga, promosi, dan distribusi ide - ide, barang - barang dan

8 Bagaimanapun juga KJKS merupakan koperasi, sehingga karakteristik dasarnya tetaplah koperasi. Lihat: Nafi' Mubarok, Buku Diktat Hukum Dagang (Surabaya: Fakultas Syariah dan Hukum Universitas Sunan Ampel, 2016), 82. 
jasa untuk menciptakan pertukaran yang memuasakan tujuantujuan individual dan organisasi. ${ }^{9}$

Menyikapi perubahan lingkungan dengan tepat dan bijak, maka akan membawa perusahaan pada titik dimana perusahaan mampu merealisasikan tujuannya, apabila perusahaan salah menyikapi maka akan membawa perusahaan pada kegagalan dan ketidak berhasilan. Sikap perusahaan inilah yang biasa disebut dengan strategi, strategi itu merupakan satu kesatuan rencana yang komprehensif dan terpadu yang menghubungkan internal perusahaan dengan situasi lingkungan eksternal agar tujuan perusahaan dapat tercapai. ${ }^{10}$

Strategi direncanakan atas dasar tujuan yang hendak dicapai sehingga dalam mencapai sebuah tujuan strategi memberikan sebuah gambaran bagaimana mencapai tujuan tersebut. Perusahaan didirikan pasti memiliki tujuan dan proses yang berbeda walaupun secara dasar tujuan setiap perusahaan adalah sama, yaitu sama - sama berusaha untuk menghasilkan laba atau keuntungan yang maksimal dari adanya pertukaran barang ataupun jasa perusahaan. Apabila tujuan perusahaan ialah untuk meghasilkan keuntungan yang maksimal tersebut maka tujuan dari kegiatan pemasaran perusahaan adalah untuk membuat penjualan berlebihan dengan jalan memahami konsumen dengan sebaik-baiknya sehingga produsen mampu menghasilkan produk atau jasa yang sesuai dan terjual dengan sendirinya. ${ }^{11}$

Usaha untuk mencapai kapasitas yang berlebihan, masing-masing perusahaan memiliki strategi pemasaran yang berbeda-beda. Strategi pemasaran ialah logika pemasaran yang dipakai dalam unit bisnis untuk mencapai sebuah tujuan pemasaran. $^{12}$ Penentuan strategi ini dapat dilakukan oleh

9 Pandji Anoraga, Management Bisnis (Jakarta: Rineka Cipta, 1997), 215.

10 Napa J. Awat, Manajemen Strategi (Yogyakarta: Liberty, 1989), 20.

11 Philip Kotler dan Gery Amstrong, Prinsip-prinsip Pemasaran (Jakarta: Erlangga, 1997), 55.

12 Kotler dan Amstrong, 416. 
manajer pemasaran dengan membuat tiga macam keputusan yaitu, konsumen manakah yang akan dituju, kepuasan seperti apa yang diinginkan oleh konsumen tersebut dan bauran pemasaran apakah yang dipakai untuk memberikan kepuasan kepada konsumen tersebut. ${ }^{13}$

Tahapan dalam merancang dan merumuskan strategi pemasaran ialah: ${ }^{14}$

a. Konsumen yang dituju (target consumer).

b. Menentukan keinginan konsumen

Strategi pemasaran merupakan sekumpulan variablevariable tentang produk, harga, distribusi, dan pemasaran yang merupakan variabel kebijakan dalam strategi pemasaran. Strategi pemasaran merupakan seperangkat alat yang dapat digunakan pemasar untuk membentuk karakteristik barang atau jasa yang ditawarkan kepada pelanggan. Jerome Mc-Carthy dalam Fandy Tjiptono merumuskan strategi pemasaran menjadi 4P (product, price, promotion and place). ${ }^{15}$

\section{Pemasaran dalam Ekonomi Islam}

Rintisan pemikiran ekonomi syariah di Indonesia dimulai pada periode awal 1980-an, melalui diskusi-diskusi dengan tokoh-tokoh Karnaen A. Perwataatmadja, M. Dawam Rahardjo, AM. Saefuddin, dan M. Amien Azis. Untuk pertama kalinya, Bank Syariah berdiri di Indonesia pada tahun 1992, dan menjadi satu-satunya yang beroperasi hingga 1998. Baru setelah lahirnya Undang-undang Perbankan Nomor 10 tahun 1998, lahir bank syariah lain dan berkembang dengan pesat. ${ }^{16}$

Menurut prinsip syariah, kegiatan pemasaran harus dilandasi semangat beribadah kepada Allah SWT, berusaha

13 Basu Swastha, Manajemen Pemasaran Modern (Yogyakarta: Liberty, 2000), 70.

14 Swastha, 71-75.

15 Marwan Asri, Marketing (Yogyakarta: UPP AMP YKPN, 1991), 47.

16 Mubarok, "Lembaga Keuangan Syariah sebagai Mustah\}iqq Zaka>h," 365. 
semaksimal mungkin untuk kesejahteraan bersama, bukan untuk kepentingan golongan apalagi kepentingan sendiri.

Rasulullah SAW telah mengajarkan pada umatnya untuk berdagang dengan menjunjung tinggi etika keislaman. Dalam beraktivitas ekonomi, umat Islam dilarang melakukan tindakan bathil. Namun harus melakukan kegiatan ekonomi yang dilakukan saling ridho, sebagaimana firman Allah SWT. dalam QS. al-Nisa': 29, yang artinya: "Hai orang-orang yang beriman, janganlah kamu saling memakan harta sesamamu dengan jalan yang bathil, kecuali dengan jalan perniagaan yang berlaku dengan suka sama suka di antara kamu. Dan janganlah kamu membunuh dirimu; sesungguhnya Allah adalah Maha Penyayang kepadamu."17

Semua aktivitas kehidupan perlu dilakukan berdasarkan perencanaan yang baik. Islam Agama yang memberikan sintesis dan rencana yang dapat direalisasikan melalui rangsangan dan bimbingan. Perencanaan tidak lain memanfaatkan "karunia Allah" secara sistematik untuk mencapai tujuan tertentu, dengan memperhatikan kebutuhan masyarakat dan nilai kehidupan yang berubah-ubah.

Pelaksanaan rencana pemasaran dalam Islam tergantung pada prinsip syarikat (kerjasama) yang telah diakui secara universal. Hal ini berarti pelaksanaan perencanaan dilaksanakan melalui partisipasi sektor pemerintah dan swasta atas dasar kemitraan. Yakni terlaksana melalui prinsip abadi mudärabah, yakni tenaga kerja dan pemilik modal dapat disatukan sebagai mitra. ${ }^{18}$

Dalam sistem perencanaan Islam, kemungkinan rugi sangat kecil karena merupakan hasil kerjasama antara sektor pemerintahan dan swasta. Investasi yang sehat akan mendorong kelancaran arus kemajuan ekonomi menjadi lebih

17 Departemen Agama RI, Al-Qur'an Dan Terjemahannya (Semarang: Tanjung Mas Inti, 1992), 122.

18 Pada dasarnya prinsip kemitraan dalam figh muamalah bisa berupa mud\}a>rabah atau musya $>$ rakah. Lihat: Mubarok, "Tinjauan Hukum Islam Terhadap Prinsip Bagi Hasil dalam Perbankan," 181. 
banyak. Dalam kegiatan pemasaran, tentu lebih dahulu menyusun perencanaan strategis untuk memberi arah terhadap kegiatan perusahaan yang menyeluruh, yang harus didukung rencana pelaksanaan lebih rinci di bidang - bidang kegiatan perusahaan.

Dalam Islam, bukanlah suatu larangan bila seorang hamba mempunyai rencana atau keinginan untuk berhasil dalam usahanya. Namun dengan syarat, rencana itu tidak bertentangan dengan ajaran (syariat) Islam. Dilandaskan dalam Al-Qur'an, yang artinya: "Atau apakah manusia akan mendapat segala yang diciptakannya? Tidak, maka hanya bagi Allah kehidupan akhirat dan kehidupan dunia." (QS. An-Najm: 24 25). ${ }^{19}$

Dari ayat tersebut, bila dihubungkan dengan strategi pemasaran, kegiatan strategi (rencana) pemasaran merupakan suatu interaksi yang berusaha untuk menciptakan atau mencapai sasaran pemasaran seperti yang diharapkan untuk mencapai keberhasilan. Dan sudah menjadi sunnatullah bahwa apa pun yang sudah kita rencanakan, berhasil atau tidaknya, ada pada ketentuan Tuhan (Allah).

Selain itu, dalam kegiatan perdagangan (muamalah), Islam melarang adanya unsur manipulasi (penipuan), sebagaimana Hadits Nabi Muhammad saw.: "Sesungguhnya ia memanipulasi (iklan dagang) kemudian menghilangkan keberkahan." (HR. Muslim, An - Nasa'i dan Ibnu Majah).20

Islam menganjurkan umatnya untuk memasarkan atau mempromosikan produk dan menetapkan harga yang sebenarnya, tidak berbohong alias harus berkata jujur. Pada dasarnya ada tiga unsur etika yang harus dilaksanakan oleh seorang produsen Muslim, yakni bersifat jujur, amanat dan nasihat. ${ }^{21}$

19 Departemen Agama RI, Al-Qur'an Dan Terjemahannya, 873.

20 Muhammad Bin Ahmad Al-Adawi, Miftahul Khithobah (Beirut: Da>r Ih\}ya' al-Kutub al-Arabiyyah, 1341), 192.

${ }^{21}$ Departemen Agama RI, Al-Qur'an Dan Terjemahannya, 586. 
Dalam Hadits yang diriwayatkan Muslim, Rasulullah saw. mencontohkan kategori pemasaran yang dilarang di dalam Islam: "Dari Abu Hurairah ra., bahwasannya Rasulullah saw. pernah melalui suatu onggokan makanan yang akan dijual. Lantas Beliau memasukkan tangan Beliau ke dalam onggokan itu, tiba - tiba di dalamnya tangan Beliau meraba makanan yang basah, kemudian Beliau keluarkan jari Beliau yang basah itu seraya berkata, "Apakah ini?" lalu yang menjual makanan berkata, "Basah karena hujan wahai Rasulullah!", kemudian Rasulullah SAW berkata, "Mengapa tidak engkau taruh di bagian atas supaya dapat dilihat orang?”, "Barang siapa yang menipu, maka ia bukan umatku!". (H.R. Muslim). ${ }^{22}$

Sistem pemasaran tentu punya strategi. Strategi pemasaran sebenarnya dapat dijelaskan sebagai cara melakukan segmentasi pasar dan tempat pembidikan pasar, strategi produk, strategi harga, tempat dan strategi pemasaran. Pasar yang menonjol pada masa Nabi Muhammad saw. adalah pasar konsumen. Berikut penjabarannya.

Segmentasi pasar dan pembidikan pasar. Terdiri atas segmentasi geografis, demografis, psikografi; segmentasi perilaku dan segmentasi manfaat. Segmentasi geografis membagi pasar menjadi unit-unit geografis berbeda. Segmentasi demografi yang dilakukan Nabi Muhammad saw. adalah pasar yang dikelompokkan berdasarkan keluarga, kewarganegaraan dan kelas sosial. Untuk keluarga, Nabi Muhammad saw. menyediakan produk peralatan rumah tangga. Sedangkan produk yang dijual Nabi Muhammad saw. untuk warga negara asing di Busra terdiri dari kismis, parfum, kurma kering, barang tenunan, batangan perak dan ramuan.

Segmentasi psikografi yang dilakukan Nabi Muhammad saw. adalah mengelompokkan pasar dalam gaya hidup, nilai dan kepribadian. Gaya hidup ditunjukkan oleh orang yang menonjol daripada kelas sosial. Minat terhadap suatu produk dipengaruhi oleh gaya hidup, maka barang yang dibeli oleh orang - orang tersebut untuk menunjukkan gaya hidupnya. Nabi Muhammad

${ }^{22}$ Al-Adawi, Miftahul Khithobah, 193-94.

Al-Qānūn, Vol. 20, No. 1, Juni 2017 
saw. mengetahui kebiasaan orang Bahrain, cara hidup penduduknya, mereka minum dan cara mereka makan.

Segmentasi perilaku yang dilakukan Nabi Muhammad saw. adalah dengan membagi kelompok berdasarkan status pemakai, kejadian, tingkat penggunaan, status kesetiaan, tahap kesiapan pembeli, dan sikap.

Pasar dikelompokkan menjadi bukan pemakai, bekas pemakai, pemakai potensial, pemakai pertama kali dan pemakai tetap dari suatu produk, atau manfaat yang terkandung dalam suatu produk.

Di dalam konsep marketing mix islami ternyata didapat bahwasannya dalam melakukan suatu pemasaran, baik barang maupun jasa, tidaklah bebas nilai. Sebagai seorang khalifah di muka bumi, manusia juga dituntut untuk menjaga kesejahteraan masyarakat secara umum, dengan berdagang menggunakan cara yang halal dan diridhoi oleh Allah SWT. Kajian lanjutan dapat dilakukan dengan mengkaji lebih dalam dan lebih luas lagi tentang manajemen pemasaran dalam Islam. Sehingga nantinya akan didapat suatu konsep manajemen pemasaran syariah yang kompleks dan komprehensif, yang nantinya dapat digunakan untuk memperkaya khasanah manajemen pemasaran syariah.

Berkaitan dengan bauran pemasaran konvensional, maka penerapan dalam syariah akan merujuk pada konsep dasar kaidah fikih. Yakni: "Tidak sempurnalah suatu kewajiban kecuali dengannya maka menggunakannya menjadi wajib". ${ }^{23}$

Dalam konsep Al-Qur'an tentang bisnis juga sangat komprehensif, parameter yang dipakai tidak menyangkut dunia saja, namun juga menyangkut urusan akhirat. Al-Qur'an memandang kehidupan manusia sebagai sebuah proses yang berkelanjutan. Manusia harus bekerja bukan hanya untuk meraih sukses di dunia namun juga kesuksesan di akhirat. ${ }^{24}$ Konsep bisnis menurut Islam selalu kembali kepada dua aspek

23 Nasrun Haroen, Ushul Fiqh, Jilid 1 (Jakarta: Logos Wacana Ilmu, 1996), 171.

24 Ahmad Mustag, The Furture of Economics: An Islamic Perspektif (Jakarta: Asy Syaamil Press \& Grafika, 2001), 35. 
yaitu kebaikan (keberuntungan) dan kejelekan (kerugian). Bisnis yang dikatakan beruntung mengandung tiga elemen dasar, yaitu:

a. Mengetahui investasi yang paling baik

b. Membuat keputusan yang logis, sehat dan masuk akal

c. Mengikuti perilaku yang baik.

Rasulullah saw. adalah Nabi terakhir yang diturunkan untuk menyempurnakan ajaran-ajaran Allah SWT yang diturunkan sebelumnya. Rasulullah SAW adalah suri tauladan untuk umat-Nya. Beliau telah memberikan contoh yang sangat baik dalam setiap transaksi bisnisnya. Beliau melakukan transaksi-transaksi secara jujur, adil dan tidak pernah membuat pelanggannya mengeluh, apalagi kecewa. Selalu menepati janji dan mengantarkan barang dagangannya dengan standar kualitas yang sesuai dengan permintaan pelanggan. Reputasinya sebagai pedagang yang jujur, telah tertanam dengan baik sejak muda. Beliau selalu memperlihatkan rasa tanggung jawab terhadap setiap transaksi yang dilakukan. ${ }^{25}$

Secara komprehensif, ada sembilan etika pemasaran lain yang perlu menjadi dasar-dasar atau prinsip bagi syariah marketer dalam menjalankan fungsi pemasaran, yaitu:26

a. Memiliki kepribadian spiritual (takwa)

b. Berperilaku baik dan simpatik (shidq)

c. Berlaku adil dalam bisnis (al-adl)

d. Bersikap melayani dan rendah hati (khidmah)

e. Menepati janji dan tidak curang

f. Jujur dan terpercaya (al-amanah)

g. Tidak suka berburuk sangka (su'udzan)

h. Tidak suka menjelek - jelekkan (ghibah)

i. Tidak melakukan sogok (riswah)

Apabila kita tinjau dari perspektif Islam haruslah sesuai dengan ajaran - ajaran agama Islam. Pada zaman Nabi Muhammad saw., beliau saw. juga menggunakan strategi

25 Hermawan Kartajaya dan Muhammad Syakir Syula, Syariah Marketing (Bandung: Mizan, 2006), 43.

${ }^{26}$ Kartajaya dan Syula, 67. 
pemasaran dalam perdagangan. Prinsip-prinsip yang digunakan Nabi Muhammad saw. berbeda dengan strategi pemasaran yang dilakukan pada saat ini. Konsepnya tidak terlepas dari nilai-nilai moralitas dan sesuai dengan etika serta estetika keislaman.

\section{Simpanan dan Pembiayaan}

Simpanan adalah seluruh dana yang dihasilkan dari produk penghimpunan dana pada perbankan syariah atau Koperasi Jasa Keuangan Syariah (KJKS), seperti giro wadiah, tabungan wadiah, dan tabungan atau deposito mudharabah. ${ }^{27}$

Dalam hal ini, dinyatakan bahwa semakin besar sumber dana yang ada di bank atau koperasi semakin besar pula bank dapat menyalurkan pembiayaan. Pelayanan jasa simpanan berupa bentuk simpanan yang terikat dan tidak terikat atas jangka waktu dan syarat - syarat tertentu dalam penyertaan dan penarikannya. Berkaitan dengan itu jenis simpanan yang dapat dikumpulkan sangat beragam sesuai dengan kebutuhan kemudahan yang dimiliki simpanan tersebut. ${ }^{28}$

Menurut undang-undang No. 10/1998 tentang perbankan: pembiayaan berdasarkan prinsip syariah adalah berdasarkan persetujuan atau kesepakatan antara bank dengan mengembalikann uang atau tagihan tersebut setelah jangka waktu tertentu dengan imbalan atau bagi hasil.

Dan dalam perbankan syariah sebenarnya penggunaan kata pinjam meminjam kurang tepat digunakan disebabkan dua hal: pertama, pinjaman merupakan salah satu metode hubungan finansial dalam Islam. Kedua, pinjam meminjam adalah akad komersial yang artinya bila seseorang meminjam sesuatu ia tidak boleh di syaratkan untuk memberikan tambahan atas pokok pinjamannya, karena setiap pinjaman yang menghasilkan manfaat adalah riba, sedangkan para ulama' sepakat bahwa riba

27 Mubarok, Buku Ajar Mahasiswa: Hukum Asuransi dan Koperasi di Indonesia, 140.

28 Muhammad, Lembaga-lembaga Keuangan Umat Kontemporer (Yogyakarta: UII Press, 2000), 117-18. 
itu haram. Oleh karena itu dalam perbankan syariah, pinjaman tidak disebut kredit akan tetapi disebut pembiayaan. ${ }^{29}$

Macam - macam simpanan dalam KJKS adalah:

a. Simpanan Pokok

Simpanan Pokok adalah simpanan yang di bayar setahun sekali atau sekali selama menjadi anggota. Besarnya simpanan bergantung dari hasil kesepakatan pengurus dan anggota koperasi. Simpanan hanya bisa di ambil kembali ketika keluar dari keanggotaan Koperasi. ${ }^{30}$

b. Simpanan Wajib

Simpanan Wajib adalah simpanan yang wajib di bayar sebulan sekali. Besarnya simpanan bergantung dari hasil kesepakatan pengurus dan anggota koperasi. Simpanan hanya bisa di ambil kembali ketika keluar dari keanggotaan Koperasi. ${ }^{31}$

c. Simpanan Suka Rela

Simpanan Suka Rela adalah simpanan yang besarnya tidak di tentukan, tetapi bergantung kepada kemampuan anggota. Simpanan sukarela dapat di setorkan dan diambil setiap saat. ${ }^{32}$

Sedangkan macam-macam pembiayaan dalam KJKS adalah:

a. Pembiayaan Produksi, yaitu pembiayaan yang ditujukan untuk memenuhi kebutuhan produksi, pedagangan, maupun investasi.

b. Pembiayaan Konsumsi, yaitu pembiayaan yang digunakan untuk memenuhi kebutuhan konsumsi yang akan habis digunakan untuk memenuhi kebutuhannya. ${ }^{33}$

29 Muhammad Syafi'i Antonio, Bank Syariah dari Teori ke Praktek (Jakarta: Gema Insani Press-Tazkia Cendikia, 2001), 170.

30 Mubarok, Buku Ajar Mahasiswa: Hukum Asuransi dan Koperasi di Indonesia, 122.

31 Mubarok, 123.

32 Mubarok, 123.

${ }^{33}$ Muhammad, Lembaga-lembaga Keuangan Umat Kontemporer, 22. 


\section{Penerapan Strategi Pemasaran Simpanan dan Pembiayaan di KJKS Manfaat Surabaya}

\section{Profil KJKS Manfaat Surabaya}

Pada tanggal 29 Desember 2006, dibentuklah sebuah Koperasi Jasa Keuangan Syariah (KJKS) yang diberi nama Koperasi Jasa Keuangan Syariah (KJKS) "Manfaat" yang berjenis usaha Jasa Keuangan Syariah. KJKS ini mulai beroperasi pada tanggal 11 April 2007. Kantor pusat KJKS Manfaat Surabaya bertempat di Jl. Perumdos ITS blok W no. 10 Surabaya - Jawa Timur. Selain itu, KJKS Manfaat juga membuka kantor operasional di Jl. Gayung Kebonsari no.46, Ruko Graha Indah, kav. A-7 Surabaya dengan nomor telepon: (031) 72468620. Email KJKS Manfaat Surabaya: kjksmanfaat@mail.com, dan WebBlog KJKS Manfaat Surabaya: http://www.kjksmanfaat.blogspot.com.

Status KJKS Manfaat sebagai sebuah lembaga yang berbadan Hukum didapat pada tanggal: 11 April 2007 dengan Nomor Badan Hukum: 63/BH/XVI.37/2007.34 Selain itu, KJKS Manfaat juga dilengkapi dengan kelengkapan usaha berupa SIUP, TDP, dan Nomor Pokok Wajib Pajak (NPWP) No. 02.607.444.3-606.000.35

Tujuan KJKS Manfaat Surabaya adalah sebagai berikut:

a. Mewujudkan ekonomi umat Islam agar lebih produktif dalam dunia kerja.

b. Menciptakan peluang lapangan pekerjaan bagi pembangunan ekonomi dan kesejahteraan umat Islam.

c. Memperluas lingkup usaha kerja dalam mengembangkan wirausahawan.

d. Membangun lembaga-lembaga kecil agar lebih tertata manajemennya.

e. Membantu pendanaan untuk para pengusaha mikro.

34 Status badan hukum ini penting, karena berdasarkan Pasal 9 Undang-Undang Perkoperasian, bahwa: "Koperasi memperoleh status badan hukum setelah akta pendiriannya disahkan oleh Pemerintah." Lihat: Mubarok, Buku Diktat Hukum Dagang, 86.

35 Tim Penyusun, “KJKS Manfaat Surabaya,” 2010. 
f. Membentuk dan membina kualitas sumber daya Insani pengusaha mikro.

g. Membantu pemerintah dalam mengurangi pengangguran. ${ }^{36}$

Visi KJKS Manfaat Surabaya adalah: "Memberikan manfaat dan kesejahteraan kepada anggota, usaha mikro (usaha kecil) dan stake holder (agar para anggota bisa mengembangkan usaha mikronya)". Sedangkan misi dari KJKS Manfaat Surabaya adalah sebagai berikut:

a. Mengembangkan lembaga keuangan Islam yang kuat, terpercaya dan memiliki jaringan yang luas.

b. Mengembangkan sumber daya insani yang profesional, cerdas, inovatif dan bertaqwa.

c. Memberikan kepercayaan bagi para mitra kerja serta rasa aman bagi semua kalangan yang menikmati jasa lembaga ini.

d. Berkomitmen tinggi menjadi lembaga keuangan yang murni sesuai dengan syariah beroreantasi kepada usaha mikro (usaha kecil). ${ }^{37}$

\section{Produk dan Aplikasi Akad di KJKS Manfaat Surabaya}

Produk dan aplikasi akad di KJKS Manfaat Surabaya adalah sebagai berikut:

a. Tabungan/Simpanan

Ini merupakan produk yang melayani penyimpanan dana dari nasabah atau anggota yang telah bergabung dengan KJKS "Manfaat". Berbagai manfaat dan kemudahan dalam produk ini bisa dinikmati oleh nasabah dan anggota yang memiliki simpanan pintar ini. Adapun produk simpanan di KJKS "Manfaat" adalah sebagai berikut:

1) Si Ummat

2) Si Quat (Kurban Dan Aqiqah)

3) Salimah ( Simpanan Walimatul Urs'y)

4) Si Pintar (Simpanan Pendidikan Pelajar)

b. Deposito

36 "Profil dan Prinsip Dasar KJKS Manfaat Surabaya," 2012.

37 "Profil dan Prinsip Dasar KJKS Manfaat Surabaya." 
Simpanan yang penarikannya hanya dapat dilakukan dalam waktu tertentu sesuai dengan kesepakatan awal

c. Pembiayaan

Akad-akad yang dipakai dalam pembiayaan di KJKS Manfaat adalah sebagai berikut:

1) Murabahah (Pembiayaan dengan sistem jual beli secara syari'ah).

2) Mudharabah (Pembiayaan sebagai modal usaha dengan system bagi hasil).

3) Musyarakah (Tambahan modal bagi mereka yang telah menjalankan usahanya).

4) Ijaroh (Produk jasa sewa).

Sedangkan produk-produk pembiayaan di KJKS Manfaat adalah sebagai berikut:

1) CERIA (Creatif Wirausaha).

2) PUAS (Pengusaha \& Pegawai Sukses).

3) M - MEGA PRO (Manfaat Mega Proyek).

4) M - 90 BISA (Manfaat 90 Bisa).

5) M - 3 (Manfaat Mitra Mandiri).

\section{Peranan Strategi Pemasaran bagi KJKS Manfaat Surabaya serta bentuknya}

Peranan strategi pemasaran bagi KJKS Manfaat memiliki peranan yang sangat penting untuk pencapaian tujuan, karena strategi memberikan arah tindakan, dan cara bagaimana tindakan tersebut harus dilakukan agar tujuan yang diinginkan tercapai. Menurut manajer KJKS Manfaat Surabaya, peranan strategi sangatlah penting untuk pengembangan pemasaran bagi KJKS Manfaat Surabaya. ${ }^{38}$

Kegiatan pemasaran yang dilakukan KJKS Manfaat Surabaya mencakup 5 bauran, yaitu:

a. Periklanan (Advertising)

Kegiatan periklanan yang dilakukan oleh KJKS Manfaat Surabaya adalah:

38 Saifuddin, Wawancara, 15 Januari 2014, Surabaya. 
1) Periklanan yang bersifat umum, diantaranya adalah pemasangan iklan di brosur-brosur tentang KJKS Manfaat Surabaya. Tujuan umum dari periklanan yang bersifat umum ini adalah untuk mempromosikan nama KJKS Manfaat Surabaya secara umum ke seluruh lapisan masyarakat di Indonesia terutama daerah surabaya dan sekitarnya. $^{39}$

2) Periklanan yang bersifat khusus, dengan tujuan untuk meningkatkan penjualan produk simpanan dan pembiayaan KJKS Manfaat Surabaya dan mempertahankan citra (brand image) KJKS Manfaat Surabaya. Adapun media pemasaran yang digunakan adalah: (1) media cetak, (2) media elektronik, dan advertensi luar ruangan (out door). ${ }^{40}$

b. Pemasaran (Marketing), yaitu dengan melakukan pendekatan pemasaran penjualan kepada pihak anggota dan pihak calon anggota, dengan berupa fee. ${ }^{41}$

c. Publisitas (Publicity), dengan melakukan kunjungan sehingga diharapkan komunikasi antara koperasi dan anggota tetap terjaga. ${ }^{42}$

d. Penjualan Perseorangan (Personal Selling), dengan menempatkan tenaga pemasar langsung (sales executive) di lokasi di sekitar Kota dan sekitarnya. ${ }^{43}$

e. Penjualan Langsung (Direct Marketing), antara lain melalui direct mail, yaitu bentuk promosi yang digunakan untuk menyampaikan informasi secara langsung kepada konsumen melalui surat, telepon, ataupun email. ${ }^{44}$

\section{E. Analisis Strategi Pemasaran Simpanan dan Pembiayaan KJKS Manfaat Surabaya}

\footnotetext{
${ }^{39}$ Saifuddin.

40 Saifuddin.

41 Saifuddin.

42 Saifuddin.

43 Saifuddin.

${ }^{44}$ Saifuddin.
} 


\section{Peranan Pemasaran KJKS Manfaat Surabaya}

KJKS Manfaat melakukan kegiatan pemasaran berupa Periklanan (Advertising), Pemasaran (Marketing), Publisitas (Publicity), Penjualan Perseorangan (Personal Selling), dan Penjualan Langsung (Direct Marketing) untuk pemasaran produk - produk KJKS Manfaat Surabaya agar konsumen dapat mengenal dan setelah mengenal dan mengetahui keunggulan yang dimiliki oleh produk-produk KJKS Manfaat Surabaya maka secara otomatis konsumen akan membelinya.

Konsumen tidak akan mengenal apalagi membeli suatu produk apabila tidak mengetahui kegunaannya, di mana produk dapat diperoleh, berapa harganya dan apa keunggulan yang dimilikinya. Setelah konsumen mengetahui kegunaan dan keunggulan yang dimiliki oleh suatu produk maka secara otomatis konsumen sudah mulai mengenal produk tersebut, dan setelah mengenalnya maka konsumen akan membelinya. Oleh sebab itu, konsumen sebagai sasaran produk atau jasa penting untuk mendapatkan informasi yang jelas dari produk atau jasa tersebut. Strategi pemasaran memiliki peranan yang sangat penting untuk pencapaian tujuan, karena strategi memberikan arah tindakan, dan cara bagaimana tindakan tersebut harus dilakukan agar tujuan yang diinginkan tercapai. Menurut manajer KJKS Manfaat Surabaya, peranan strategi sangatlah penting untuk pengembangan pemasaran bagi KJKS Manfaat Surabaya. adalah:45

Peranan strategi pemasaran bagi KJKS Manfaat Surabaya

a. Strategi yang berperan untuk mengontrol berjalannya keefektifan dan keefesienan pemasaran. Berdasarkan yang disampaikan oleh Syaifuddin strategi yang berjalan efektif dan efesien menunjukkan bahwa pemasaran yang dilakukan KJKS Manfaat Surabaya berjalan dengan baik. Artinya efektif atau tidaknya penerapan strategi menjadi tolok ukur yang efektif atau tidaknya pemasaran yang dilakukan oleh KJKS Manfaat Surabaya, begitu juga

45 Saifuddin. 
sebaliknya. Sehingga bila KJKS Manfaat Surabaya menargetkan tercapainya pemasaran yang efektif dan efisien, maka strategi pemasaran yang diterapkan KJKS Manfaat harus dikerjakan seefektif dan seefisien mungkin, mengingat fungsinya sebagai tolok ukur baik atau tidaknya pemasaran KJKS Manfaat Surabaya.

b. Strategi yang berfungsi untuk membuat bisnis planing 3 bulan sekali. Berdasarkan yang disampaikan oleh Syaifuddin, strategi telah dijadikan sebagai landasan dalam membuat bisnis planing. Hal ini menunjukkan bahwa strategi berperan sebagai pendukung untuk pengambilan keputusan.

c. Strategi yang berperan untuk menguji seberapa efektif pekerjaan pemasar. Berdasarkan pernyataan tersebut strategi yang berjalan efektif menunjukkan bahwa pemasar telah mengerjakan strategi yang diterapkan dengan baik. Artinya efektif atau tidaknya penerapan strategi menjadi tolok ukur yang efektif atau tidaknya pemasar dalam memasarkan produk KJKS Manfat Surabaya. Sehingga bila KJKS Manfaat Surabaya menargetkan tercapainya pemasar yang efektif, maka strategi pemasaran yang diterapkan KJKS Manfaat harus dikerjakan seefektif mungkin.

d. Strategi yang berperan untuk mengevaluasi apakah cocok atau tidaknya produk-produk KJKS Manfaat Surabaya untuk diteruskan. Berdasarkan pernyataan tersebut strategi yang berperan untuk mengevaluasi cocok atau tidaknya produkproduk KJKS Manfaat Surabaya untuk diteruskan menunjukkan bahwa strategi sebagai pendukung untuk pengambilan keputusan.

e. Strategi pemasaran yang berperan untuk mengukur keberhasilan pemasaran KJKS Manfaat Surabaya. Berdasarkan yang disampaikan oleh Syaifuddin, strategi pemasaran berperan untuk mengukur keberhasilan. Dalam penertian jika strategi pemasaran tersebut berhasil maka strategi berperan sebagai target. 


\section{Strategi Pemasaran KJKS Manfaat Surabaya}

Strategi pemasaran yang dilakukan KJKS Manfaat Surabaya mencakup 5 bauran, yaitu:

a. Periklanan (Advertising)

Kegiatan periklanan yang dilakukan oleh KJKS Manfaat Surabaya secara umum untuk mendukung penyampaian informasi kepada masyarakat agar masyarakat lebih mengetahui mengenai KJKS Manfaat Surabaya dan secara khusus untuk meningkatkan penjualan produk simpanan dan pembiayaan KJKS Manfaat Surabaya dan mempertahankan citra (brand image) KJKS Manfaat Surabaya, periklanan yang dilakukan oleh KJKS Manfaat Surabaya sudah tepat karena periklanan (alat promosi) yang digunakan perusahaan dalam menyebarkan informasi mengenai produknya kepada konsumen, bahwa produk tersebut telah tersedia di pasar dan produk tersebut mampu memberikan manfaat yang memadai serta mampu memuaskan kebutuhan konsumen.

Promosi dengan dampak positif yang diharapkan Dampak dari periklanan (alat promosi) cukup berpengaruh dalam memperkenalkan produk kepada konsumen dan dalam merayu calon konsumen agar tergerak untuk melakukan tindakan pembelian terhadap produk yang ditawarkan oleh KJKS Manfaat Surabaya.

b. Pemasaran (Marketing)

Strategi pemasaran penjualan yang dilakukan adalah dengan melakukan pendekatan pemasaran penjualan kepada pihak anggota dan pihak calon anggota untuk meningkatkan apresiasi dan loyalitas dari anggota KJKS Manfaat Surabaya maka KJKS Manfaat Surabaya secara berkala memberikan ucapan dan bingkisan ulang tahun ataupun karangan bunga. Pemasaran yang dilakukan oleh KJKS Manfaat Surabaya menunjukkan bahwa KJKS Manfaat Surabaya memberikan perhatian lebih kepada anggotanya 
agar tumbuh loyalitas dari anggota KJKS manfaat Surabaya (Mempertahankan anggota agar setia).

c. Publisitas (Publicity)

Kegiatan publisitas yang dilakukan diantaranya adalah kunjungan ke anggota KJKS Manfaat Surabaya sehingga diharapkan komunikasi antara koperasi dan anggota tetap terjaga. Kegiatan publisitas yang dilakukan oleh KJKS Manfaat Surabaya dengan melakukan kunjungan ke anggota menunjukkan bahwasannya KJKS Manfaat Surabaya menjaga keharmonisan dengan anggotanya.

d. Penjualan Perseorangan (Personal Selling)

Program personal selling dilakukan langsung oleh pihak manajemen KJKS Manfaat Surabaya dengan menempatkan tenaga pemasar langsung (sales executive) di lokasi di sekitar Kota dan sekitarnya. Para tenaga pemasar langsung dituntut untuk mampu berkomunikasi dengan baik kepada calon konsumen. Personal selling mempunyai peran penting dalam pelayanan KJKS Manfaat Surabaya yang melibatkan interaksi pribadi antara personal saller KJKS Manfaat Surabaya dengan nasabah atau calon nasabah membuat nasabah atau calon nasabah mempunyai hubungan tetap dengan personal saller KJKS Manfaat Surabaya, baik hubungan penjualan, pelayanan, dan pengawasan. Hubungan ini harus dijaga untuk memastikan kepuasan pelanggan telah meningkat.

e. Penjualan Langsung (Direct Marketing)

Strategi penjualan langsung (direct marketing) yang dilakukan KJKS Manfaat Surabaya untuk menjual produk dan menyampaikan informasi secara langsung kepada konsumen dan calon konsumen agar calon konsumen mengetahui informasi secara langsung tentang KJKS Manfaat Surabaya, penjualan secara langsung termasuk salah satu staregi pemasaran yang cukup efektif bagi KJKS Manfaat karena dengan adanya penjualan secara langsung penjualan produk dan penyampainnya lebih jelas. 


\section{F. Penutup}

Berdasarkan berbagai uraian sebelumnya, maka bisa disimpulkan:

1. Peranan pemasaran KJKS Manfaat Surabaya dalam usaha memperkenalkan produk simpanan dan pembiayaan kepada konsumen sangatlah penting dan juga menjadi salah satu keberhasilan suatu perusahaan untuk memperoleh laba, untuk pengembangan produk-produknya, untuk kelangsungan usahanya, serta untuk kelangsungan usahanya, KJKS Manfaat melakukan kegiatan pemasaran berupa Periklanan, Pemasaran, Publisitas, Penjualan Perseorangan, dan Penjualan Langsung.

2. Strategi pemasaran yang dilakukan oleh KJKS Manfaat Surabaya dalam upaya memperkenalkan dan memasarkan produk simpanan dan pembiayaan adalah dengan menjalin kerja sama dengan anggota yang bekerja sama dengan KJKS Manfaat Surabaya, melalui media cetak, iklan, pameranpameran dan melalui trend umum yang saat ini dianggap sangat mudah dan praktis dalam menyampaikan informasi sebuah produk oleh pihak pemasar baik Koperasi maupun perusahaan-perusahaan bisnis lainnya, yakni melalui jaringan Social Media.

\section{Daftar Pustaka}

Al-Adawi, Muhammad Bin Ahmad. Miftahul Khithobah. Beirut: Dār Ihya' al-Kutub al-Arabiyyah, 1341.

Anoraga, Pandji. Management Bisnis. Jakarta: Rineka Cipta, 1997. Antonio, Muhammad Syafi'i. Bank Syariah dari Teori ke Praktek. Jakarta: Gema Insani Press-Tazkia Cendikia, 2001. Arafat, W. Behind a Powerfull Image: Menggenggam Strategi dan Kunci-kunci Sukses Menancapkan Image Perusahaan yang Kokoh. Yogyakarta: Andi, 2006.

Asri, Marwan. Marketing. Yogyakarta: UPP AMP YKPN, 1991. Awat, Napa J. Manajemen Strategi. Yogyakarta: Liberty, 1989. 
Departemen Agama RI. Al-Qur'an Dan Terjemahannya. Semarang: Tanjung Mas Inti, 1992.

Haroen, Nasrun. Ushul Fiqh. Jilid 1. Jakarta: Logos Wacana Ilmu, 1996.

Kartajaya, Hermawan, dan Muhammad Syakir Syula. Syariah Marketing. Bandung: Mizan, 2006.

Kotler, Philip, dan Gery Amstrong. Prinsip-prinsip Pemasaran. Jakarta: Erlangga, 1997.

Mubarok, Nafi'. Buku Ajar Mahasiswa: Hukum Asuransi dan Koperasi di Indonesia. Surabaya: Fakultas Syariah IAIN Sunan Ampel, 2013.

-_—. Buku Diktat Hukum Dagang. Surabaya: Fakultas Syariah dan Hukum Universitas Sunan Ampel, 2016.

——_. Hukum Dagang: Buku Perkuliahan. Surabaya: IAIN Press, 2015.

_—_. "Lembaga Keuangan Syariah sebagai Mustahiqq Zakāh." Jurnal Al-Qänün 13, no. 2 (Desember 2010).

- - - "Tinjauan Hukum Islam Terhadap Prinsip Bagi Hasil dalam Perbankan." Maliyah 1, no. 2 (Desember 2011).

Muhammad. Lembaga-lembaga Keuangan Umat Kontemporer. Yogyakarta: UII Press, 2000.

Mustag, Ahmad. The Furture of Economics: An Islamic Perspektif. Jakarta: Asy Syaamil Press \& Grafika, 2001.

"Profil dan Prinsip Dasar KJKS Manfaat Surabaya," 2012.

Rizal, M. "Implementasi Strategi CRM untuk Meningkatkan Kepuasan dan Loyalitas Pelanggan." SKEMA 1, no. 3 (November 2013).

Saifuddin. Wawancara, 15 Januari 2014. Surabaya.

Swastha, Basu. Manajemen Pemasaran Modern. Yogyakarta: Liberty, 2000.

Tim Penyusun. "Koperasi Jasa Keuangan Syariah (KJKS) Manfaat Surabaya," 2010. 